(c) American Dairy Science Association, 2006.

\title{
Trends in Calving Ages and Calving Intervals for Dairy Cattle Breeds in the United States
}

\author{
E. Hare, ${ }^{1}$ H. D. Norman, ${ }^{2}$ and J. R. Wright \\ Animal Improvement Programs Laboratory, Agricultural Research Service, USDA, Beltsville, MD 20705-2350
}

\begin{abstract}
Trends since 1980 for calving age and calving interval, 2 factors that influence herd life, were examined by parity for 5 breeds of US dairy cattle. Calving data were from cows with records that passed edits for USDA genetic evaluations and were in herds that remained on Dairy Herd Improvement test. First-calf heifers calved at progressively younger ages over time, but the age decline was less for later parities because of longer calving intervals. Breed differences for calving age were evident for all parities; current mean age at first calving ranged from 24 mo for Jerseys to 28 mo for Ayrshires. Mean calving age across all parities declined over time for all breeds, primarily because of increased turnover rate, and ranged from 48 mo for Holsteins to 54 mo for Ayrshires. Across parity, annual increase in calving interval was reasonably consistent $(0.90$ to $1.07 \mathrm{~d} / \mathrm{yr})$ for all breeds except Jersey $(0.49 \mathrm{~d} / \mathrm{yr})$. Within parity, regressions of calving interval on year were generally similar to overall breed trend. Breed means for first calving interval across time ranged from $390 \mathrm{~d}$ for Jerseys to $407 \mathrm{~d}$ for Brown Swiss.
\end{abstract}

Key words: breed, calving age, calving interval, parity

\section{INTRODUCTION}

The productive life of a dairy cow is an indication of her utility and is influenced by her age at first calving, calving intervals, length of each lactation, and success in surviving to another lactation. Age at first calving includes the period that a cow needs to reach maturity and to reproduce for the first time; calving intervals reflect the periods that a cow reproduces again. Dairy cows that fail to conceive are destined for early culling. These indicators of reproductive success impact the economic outcome of the dairy enterprise (VanRaden and Klaaskate, 1993; Gröhn and Rajala-Schultz, 2000). Nevertheless, each trait is influenced extensively by dairy management practices.

Received June 20, 2005.

Accepted August 26, 2005.

${ }^{1}$ Current address: 57 Avery Rd., Garrison, NY 10524.

${ }^{2}$ Corresponding author: dnorman@aipl.arsusda.gov
Nieuwhof et al. (1989b) provided a comprehensive examination of calving ages throughout the lifetime of US dairy cows that first calved between 1966 and 1976 . They found that age at calving for each parity was relatively stable across those $11 \mathrm{yr}$ except for significant $(P<0.05)$ increases in age for Guernseys and Holsteins after third parity. Some increased ages at calving in later parities might have resulted from a negative genetic correlation between production and reproductive traits as selection for production traits was extensive during this period (Animal Improvement Programs Laboratory, 2005). For individual parities, Jerseys were youngest, whereas Ayrshires and Brown Swiss were oldest. However, when parity was not considered, mean calving age was lowest for Guernseys and highest for Brown Swiss. Mean calving age across parities declined for Brown Swiss and Guernseys, but increased for Jerseys, which reflected changes in survival rates (Nieuwhof et al., 1989a). Three USDA studies (USDA, 2002b) on dairy health and management practices were compiled based on data from US herds in 1991, 1996, and 2002 that represented 83 to $85 \%$ of US cows. Mean age at first calving within herd declined slightly from 25.9 mo in 1991 to 25.4 mo in 2002 and declined from 25.8 to 25.0 mo when weighted for cow numbers. Mean age at first calving in 2002 was inversely related to herd size (USDA, 2002a) and within herd was 25.5 mo when herd size was $<100$ cows but only 24.6 mo when herd size was $\geq 500$ cows. Other studies have reported decreasing ages at first calving for dairy populations in The Netherlands (Nederlands Rundvee Syndicaat, 2005) and Spain (González-Recio et al., 2004).

Nieuwhof et al. (1989b) also reported that calving intervals increased in the US dairy population from first to sixth parity: 394 to 398 d for Ayrshires, 401 to $411 \mathrm{~d}$ for Brown Swiss, 400 to $407 \mathrm{~d}$ for Guernseys, 394 to $405 \mathrm{~d}$ for Holsteins, and 388 to $394 \mathrm{~d}$ for Jerseys. Linear regressions of calving interval on year of first calving were significant $(P<0.05)$ for the first calving interval of Ayrshires and Brown Swiss, the first 5 calving intervals of Holsteins, and all 6 calving intervals of Guernseys. First calving interval increased between 0.24 and $0.43 \mathrm{~d} / \mathrm{yr}$ for all breeds except Jersey, which had a decline of $0.15 \mathrm{~d} / \mathrm{yr}$. Changes in subsequent calv- 
HARE ET AL.

Table 1. Means and SD of calving ages across all parities by breed and calving year

\begin{tabular}{|c|c|c|c|c|c|c|c|c|c|c|}
\hline \multirow[b]{2}{*}{ Year } & \multicolumn{2}{|c|}{$\begin{array}{c}\text { Ayrshire } \\
(\mathrm{n}=128,898)\end{array}$} & \multicolumn{2}{|c|}{$\begin{array}{l}\text { Brown Swiss } \\
(\mathrm{n}=210,430)\end{array}$} & \multicolumn{2}{|c|}{$\begin{array}{c}\text { Guernsey } \\
(\mathrm{n}=277,225)\end{array}$} & \multicolumn{2}{|c|}{$\begin{array}{c}\text { Holstein } \\
(\mathrm{n}=18,898,376)\end{array}$} & \multicolumn{2}{|c|}{$\begin{array}{c}\text { Jersey } \\
(\mathrm{n}=1,047,278)\end{array}$} \\
\hline & Mean & SD & Mean & SD & Mean & SD & Mean & SD & Mean & SD \\
\hline & & & & & & no) & & & & \\
\hline 1980 & 57.2 & 27.8 & 58.9 & 30.2 & 54.3 & 26.9 & 51.8 & 24.8 & 54.6 & 27.8 \\
\hline 1981 & 56.0 & 27.1 & 57.2 & 29.3 & 53.3 & 26.4 & 51.3 & 24.6 & 54.2 & 27.8 \\
\hline 1982 & 55.4 & 26.6 & 56.0 & 28.3 & 52.9 & 26.0 & 51.0 & 24.5 & 53.6 & 27.6 \\
\hline 1983 & 54.9 & 26.2 & 55.3 & 28.1 & 52.0 & 25.6 & 50.4 & 24.1 & 52.9 & 27.3 \\
\hline 1984 & 55.0 & 25.7 & 55.3 & 27.4 & 51.7 & 25.0 & 50.1 & 23.6 & 52.5 & 26.8 \\
\hline 1985 & 55.0 & 25.5 & 55.4 & 27.1 & 51.1 & 24.9 & 49.8 & 23.2 & 52.2 & 26.4 \\
\hline 1986 & 54.7 & 25.4 & 55.1 & 26.9 & 50.7 & 24.5 & 49.7 & 23.0 & 51.9 & 26.1 \\
\hline 1987 & 54.3 & 25.3 & 56.0 & 27.2 & 50.1 & 24.0 & 49.6 & 23.0 & 51.8 & 25.9 \\
\hline 1988 & 53.9 & 25.2 & 55.8 & 27.4 & 49.8 & 23.9 & 49.5 & 23.0 & 51.7 & 26.0 \\
\hline 1989 & 54.1 & 25.5 & 55.6 & 27.6 & 49.4 & 23.5 & 49.0 & 23.1 & 51.2 & 25.7 \\
\hline 1990 & 54.5 & 25.7 & 56.4 & 28.6 & 49.6 & 23.5 & 48.7 & 23.0 & 50.7 & 25.6 \\
\hline 1991 & 53.5 & 25.2 & 54.6 & 27.9 & 49.1 & 23.0 & 48.2 & 22.8 & 49.9 & 25.1 \\
\hline 1992 & 53.3 & 25.1 & 53.8 & 26.9 & 48.5 & 22.7 & 47.8 & 22.6 & 49.5 & 24.7 \\
\hline 1993 & 52.9 & 25.1 & 53.2 & 26.5 & 48.3 & 22.7 & 47.4 & 22.4 & 49.2 & 24.2 \\
\hline 1994 & 52.8 & 24.4 & 52.8 & 26.0 & 48.5 & 22.8 & 47.1 & 22.1 & 49.2 & 24.0 \\
\hline 1995 & 52.6 & 24.7 & 52.6 & 25.5 & 48.7 & 23.0 & 46.9 & 21.9 & 49.5 & 24.1 \\
\hline 1996 & 53.4 & 24.6 & 53.1 & 25.7 & 49.1 & 23.0 & 46.9 & 21.8 & 50.1 & 24.4 \\
\hline 1997 & 54.4 & 25.6 & 53.2 & 25.5 & 49.5 & 23.0 & 46.8 & 21.7 & 50.2 & 24.5 \\
\hline 1998 & 54.6 & 25.3 & 53.0 & 25.7 & 49.5 & 23.4 & 46.3 & 21.5 & 50.1 & 24.6 \\
\hline 1999 & 54.5 & 25.3 & 52.7 & 25.9 & 49.2 & 23.5 & 46.0 & 21.6 & 49.3 & 24.8 \\
\hline 2000 & 54.1 & 25.3 & 52.0 & 25.8 & 48.3 & 22.7 & 45.7 & 21.6 & 48.6 & 24.7 \\
\hline 2001 & 54.9 & 25.7 & 52.0 & 25.7 & 48.2 & 23.0 & 45.5 & 21.4 & 48.0 & 24.4 \\
\hline 2002 & 54.0 & 25.6 & 51.1 & 25.3 & 47.5 & 23.0 & 45.1 & 21.4 & 47.2 & 24.2 \\
\hline 2003 & 54.1 & 25.6 & 50.9 & 25.5 & 48.1 & 23.2 & 44.7 & 21.2 & 46.5 & 23.8 \\
\hline 2004 & 54.3 & 25.8 & 51.0 & 25.2 & 48.5 & 23.1 & 44.6 & 21.2 & 46.6 & 23.7 \\
\hline All & 54.5 & 25.7 & 54.2 & 27.0 & 50.6 & 24.5 & 47.8 & 22.6 & 50.2 & 25.3 \\
\hline
\end{tabular}

ing intervals across time were similar to changes for first calving interval. Dairy 2002 (USDA, 2002b) reported mean calving interval increased from 12.8 to 13.3 mo for herds and from 12.9 to 13.4 mo across cows between 1991 and 2002. Herd size and calving interval were positively related (USDA, 2002a); mean calving interval within herd was 13.2 mo for herds with $<100$ cows and 13.7 mo for herds with $\geq 500$ cows.

Selection for high milk yield in dairy cattle generally is accompanied by a decline in fertility (Lucy, 2001). Increases in calving intervals over time have been reported recently in dairy populations in many countries, including Canada (Murray, 2003), Spain (GonzálezRecio et al., 2004), The Netherlands (Nederlands Rundvee Syndicaat, 2005), and the United Kingdom (Wall et al., 2003).

A genetic evaluation for productive life was introduced in 1994 for bulls and in 1995 for cows. Productive life was defined as the lactating period of a cow to 84 mo, but credit for DIM was restricted to the first 305 d of each lactation (VanRaden and Klaaskate, 1993). In 2003, USDA introduced genetic evaluations for daughter pregnancy rate (VanRaden et al., 2004), which provided a ranking that was equivalent to days

Table 2. Means and SD of calving ages by breed and parity for cows that first calved after 1979

\begin{tabular}{|c|c|c|c|c|c|c|c|c|c|c|}
\hline \multirow[b]{2}{*}{ Parity } & \multicolumn{2}{|c|}{$\begin{array}{c}\text { Ayrshire } \\
(\mathrm{n}=80,689)\end{array}$} & \multicolumn{2}{|c|}{$\begin{array}{l}\text { Brown Swiss } \\
(\mathrm{n}=134,763)\end{array}$} & \multicolumn{2}{|c|}{$\begin{array}{c}\text { Guernsey } \\
(\mathrm{n}=188,379)\end{array}$} & \multicolumn{2}{|c|}{$\begin{array}{c}\text { Holstein } \\
(\mathrm{n}=14,295,659)\end{array}$} & \multicolumn{2}{|c|}{$\begin{array}{c}\text { Jersey } \\
(\mathrm{n}=749,991)\end{array}$} \\
\hline & Mean & SD & Mean & SD & Mean & SD & Mean & SD & Mean & SD \\
\hline & & & & & 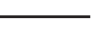 & & & & & \\
\hline 1 & 28.9 & 3.4 & 28.0 & 3.3 & 27.7 & 3.2 & 26.9 & 3.2 & 25.6 & 3.2 \\
\hline 2 & 42.1 & 4.0 & 41.4 & 4.0 & 41.0 & 3.9 & 40.1 & 4.0 & 38.4 & 3.8 \\
\hline 3 & 55.1 & 4.5 & 54.7 & 4.7 & 54.0 & 4.5 & 53.3 & 4.6 & 51.1 & 4.4 \\
\hline 4 & 68.0 & 5.1 & 67.9 & 5.3 & 67.0 & 5.1 & 66.3 & 5.3 & 63.7 & 4.9 \\
\hline 5 & 80.9 & 5.6 & 81.0 & 5.9 & 80.0 & 5.6 & 79.3 & 5.9 & 76.4 & 5.5 \\
\hline 6 & 93.7 & 6.1 & 94.1 & 6.5 & 93.0 & 6.1 & 92.3 & 6.4 & 89.1 & 6.0 \\
\hline 7 & 106.3 & 6.4 & 107.0 & 6.9 & 105.9 & 6.5 & 105.1 & 6.9 & 101.8 & 6.4 \\
\hline 8 & 119.1 & 6.9 & 120.0 & 7.5 & 118.8 & 6.9 & 117.8 & 7.4 & 114.4 & 6.9 \\
\hline
\end{tabular}


Table 3. Coefficients of linear regression of calving age on year of first calving and SE by breed and parity

\begin{tabular}{|c|c|c|c|c|c|c|c|c|c|c|}
\hline \multirow[b]{2}{*}{ Parity } & \multicolumn{2}{|c|}{ Ayrshire } & \multicolumn{2}{|c|}{ Brown Swiss } & \multicolumn{2}{|c|}{ Guernsey } & \multicolumn{2}{|c|}{ Holstein } & \multicolumn{2}{|c|}{ Jersey } \\
\hline & Coefficient & $\mathrm{SE}$ & Coefficient & SE & Coefficient & $\mathrm{SE}$ & Coefficient & SE & Coefficient & $\mathrm{SE}$ \\
\hline 1 & $-1.1^{* * *}$ & 0.05 & -1.9 & 0.04 & $-1.3 * * *$ & 0.04 & $-3.4^{* * *}$ & 0.00 & $-3.2^{* * * *}$ & 0.02 \\
\hline 2 & $-0.2^{* *}$ & 0.08 & $-1.1^{* * *}$ & 0.06 & $-0.6^{* * *}$ & 0.06 & -2.6 *** & 0.01 & $-2.7 * * *$ & 0.02 \\
\hline 3 & $0.4^{* * * *}$ & 0.12 & $-0.4^{* * *}$ & 0.09 & 0.1 & 0.09 & $-1.8 * * *$ & 0.01 & $-2.4^{* * *}$ & 0.03 \\
\hline 4 & $0.8^{* * *}$ & 0.18 & 0.3 & 0.14 & $0.9^{* * *}$ & 0.14 & $-1.3 * * *$ & 0.01 & $-2.3^{* * *}$ & 0.05 \\
\hline 5 & $1.4^{* * *}$ & 0.27 & 0.1 & 0.22 & $1.1^{* * *}$ & 0.23 & $-1.0 * * *$ & 0.02 & $-2.1^{* * *}$ & 0.08 \\
\hline 6 & $2.3^{* * * *}$ & 0.43 & 0.1 & 0.36 & $2.0 * * *$ & 0.38 & $-0.8^{* * *}$ & 0.04 & $-1.8^{* * *}$ & 0.13 \\
\hline 7 & $1.8^{* *}$ & 0.69 & 0.3 & 0.57 & $2.1^{* *}$ & 0.65 & $-0.7 * * *$ & 0.07 & $-1.5^{* * *}$ & 0.20 \\
\hline 8 & $3.2 * *$ & 1.14 & -1.1 & 0.96 & $3.8 * *$ & 1.17 & $-0.5^{* * *}$ & 0.13 & $-1.8 * * *$ & 0.33 \\
\hline All & -9.9 *** & 0.21 & $-15.1 * * *$ & 0.16 & $-10.0 * * *$ & 0.14 & $-16.6^{* * *}$ & 0.01 & $-18.3 * * *$ & 0.06 \\
\hline
\end{tabular}

open, except with the opposite sign (daughter pregnancy rate $=-0.4 \times$ days open). Nevertheless, frequent inquiries are received by USDA concerning calving and culling practices in the US. Those inquiries include requests for calving age, calving interval, percentage of cows that leave the herd overall and by parity, culling risks in relation to lactation stage, and disposal reasons, because national means and variation measures for those traits have not been readily available. The purpose of this study was to examine calving age and calving interval, 2 factors that influence herd life of US dairy cows, and to document their trends.

\section{MATERIALS AND METHODS}

Lactation records from the national dairy database at the Animal Improvement Programs Laboratory, USDA (Beltsville, MD), were used to determine calving ages and intervals across time within breed for Ayrshires, Brown Swiss, Guernseys, Holsteins, and Jerseys. Only records from cows with an identified sire and a calving

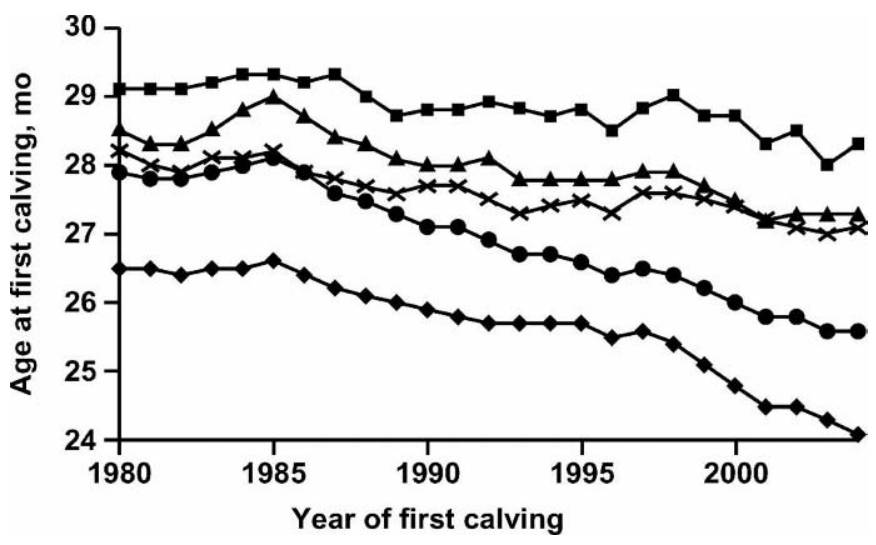

Figure 1. Trend in age at first calving by year of first calving for

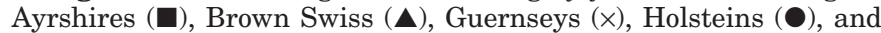
Jerseys $(\bullet)$. date after December 31, 1979, were included in the analysis. Calving age for each parity was calculated as the difference between birth date and calving date of the cow. Records for a cow were excluded if calving age was $<15$ mo or $>300$ mo. Calving interval was calculated as the difference between calving dates from successive parities and was restricted to 270 to $650 \mathrm{~d}$. Frequencies of age at first calving were compared between 1980 and 2004 to determine whether the variation had changed over time.

Records that were analyzed by parity had additional edits to ensure that data from all of the parities of the cow were present. Those edits excluded records of cows that first calved after 36 mo of age and cows that changed herds. In analysis of calving intervals, herds were required to have remained on DHI test for $650 \mathrm{~d}$ after a cow's calving date to prevent inclusion of only short calving intervals.

To determine whether trends in calving ages or intervals were significant with respect to year of first calving, linear and quadratic regressions were calculated, and

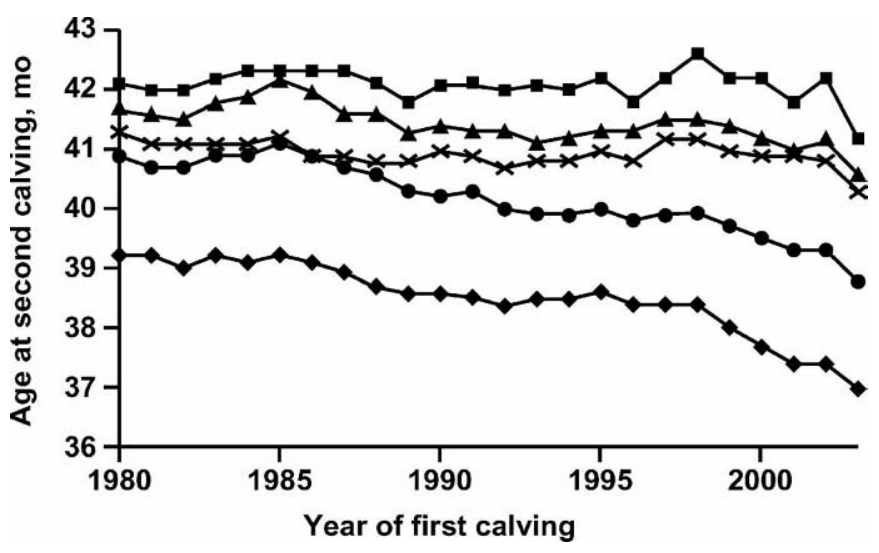

Figure 2. Trend in age at second calving by year of first calving

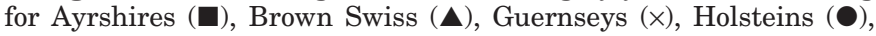
and Jerseys $(\bullet)$. 


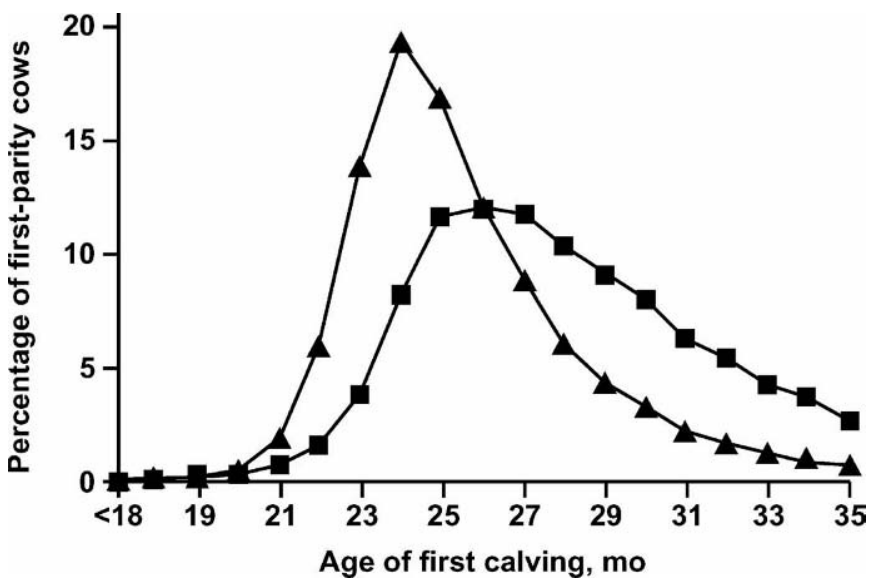

Figure 3. Distribution of calving ages for first-parity Holsteins in

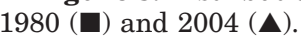

standard errors and coefficients of determination were compared within breed.

\section{RESULTS AND DISCUSSION}

Data used in analysis of calving age, regardless of parity, included lactation records of 128,898 Ayrshires, 210,430 Brown Swiss, 277,225 Guernseys, 18,898,376 Holsteins, and 1,047,278 Jerseys. Means and standard deviations by calving year are presented in Table 1 . All breeds experienced an overall decline in mean age of milking cattle. The change from 1980 to 2004 ranged from a decrease of 3 mo for Ayrshires to 8 mo for Brown Swiss and Jerseys. Regression analysis of change in calving age over time (results not shown in table) showed significant $(P<0.001)$ decreases of $0.09,0.26$, $0.26,0.29$, and $0.28 \mathrm{mo} / \mathrm{yr}$ for Ayrshires, Brown Swiss, Guernseys, Holsteins, and Jerseys, respectively. The decline in calving age over time resulted primarily from increased turnover rate, although younger ages at first (and subsequent) calvings also had an effect. For 2004 calvings, mean calving ages ranged from 44.6 mo for
Holsteins to 54.3 mo for Ayrshires. Mean calving ages for recent years are lower than those reported by Nieuwhof et al. (1989b), but exact comparisons are not possible, as the earlier study restricted animals to those with records from the first 8 parities. Brown Swiss generally had the largest standard deviations for calving age (25.2 to $30.2 \mathrm{mo}$ ), whereas Holsteins had the smallest (21.2 to $24.8 \mathrm{mo}$ ). For recent years, Ayrshires also had large standard deviations for calving age (25.6 to $25.8 \mathrm{mo}$ ). Means and standard deviations generally were positively related across time and across breeds.

To quantify changes in calving age further, records of 80,689 Ayrshires, 134,763 Brown Swiss, 188,379 Guernseys, 14,295,659 Holsteins, and 749,991 Jerseys that first calved after 1979 were analyzed by parity (Table 2). Jerseys had the lowest mean calving age for first parity ( $25.6 \mathrm{mo})$, followed by Holsteins (26.9 mo), Guernseys (27.7 mo), Brown Swiss (28.0 mo), and Ayrshires $(28.9$ mo). Breed rankings remained the same through fourth parity. The only ranking change for parities after fourth was between Ayrshires and Brown Swiss. First parity calving age has declined since the study of Nieuwhof et al. (1989b); the largest decreases were slightly longer than 1 mo for Holsteins and Jerseys. Declines for Ayrshires, Brown Swiss, and Guernseys were between 0.5 and 0.7 mo. Not surprisingly, those decreases in age at first calving for DHI cows parallel the decline $(0.5 \mathrm{mo}$ within herd and $0.8 \mathrm{mo}$ across cows) that was reported through USDA surveys in 1991 and 2002 (USDA, 2002b). The decreases might represent earlier maturity from better calf-raising practices or from intense selection for high milk yield during early parities. Similar reductions in age at first calving were also found in The Netherlands (Nederlands Rundvee Syndicaat, 2005) and Spain (González-Recio et al., 2004).

Coefficients for linear regression of calving age on year of first calving and standard errors are presented in Table 3 by breed and parity. Regression coefficients were negative for the first 2 parities of all 5 breeds and

Table 4. Means and SD for calving intervals by breed and parity

\begin{tabular}{|c|c|c|c|c|c|c|c|c|c|c|}
\hline \multirow{2}{*}{$\begin{array}{l}\text { Parity at } \\
\text { start of } \\
\text { interval }\end{array}$} & \multicolumn{2}{|c|}{ Ayrshire } & \multicolumn{2}{|c|}{ Brown Swiss } & \multicolumn{2}{|c|}{ Guernsey } & \multicolumn{2}{|c|}{ Holstein } & \multicolumn{2}{|c|}{ Jersey } \\
\hline & Mean & SD & Mean & SD & Mean & SD & Mean & SD & Mean & SD \\
\hline 1 & 399.8 & 61.0 & 406.5 & 66.3 & 405.2 & 63.2 & 402.9 & 67.3 & 390.5 & 60.7 \\
\hline 2 & 394.0 & 55.5 & 403.7 & 63.1 & 403.0 & 60.8 & 402.4 & 64.4 & 387.7 & 57.3 \\
\hline 3 & 394.8 & 55.7 & 405.6 & 64.1 & 406.7 & 61.7 & 403.4 & 64.1 & 387.9 & 56.7 \\
\hline 4 & 398.5 & 57.0 & 408.6 & 65.6 & 411.2 & 62.8 & 406.2 & 64.9 & 390.7 & 58.5 \\
\hline 5 & 399.8 & 58.0 & 413.3 & 68.3 & 413.3 & 63.1 & 408.9 & 65.9 & 393.9 & 60.5 \\
\hline 6 & 402.2 & 56.1 & 415.5 & 68.3 & 415.9 & 64.7 & 410.8 & 66.5 & 396.8 & 61.5 \\
\hline 7 & 405.7 & 59.7 & 419.2 & 71.3 & 420.5 & 68.0 & 412.9 & 67.4 & 400.2 & 63.6 \\
\hline All & 397.6 & 58.3 & 406.7 & 65.5 & 405.9 & 62.4 & 403.6 & 65.8 & 389.9 & 59.1 \\
\hline
\end{tabular}


Table 5. Coefficients of linear regression of calving interval on year of first calving and SE by breed and parity

\begin{tabular}{|c|c|c|c|c|c|c|c|c|c|c|}
\hline $\begin{array}{l}\text { Parity at } \\
\text { start of } \\
\text { interval }\end{array}$ & \multicolumn{2}{|c|}{ Ayrshire } & \multicolumn{2}{|c|}{ Brown Swiss } & \multicolumn{2}{|c|}{ Guernsey } & \multicolumn{2}{|c|}{ Holstein } & \multicolumn{2}{|c|}{ Jersey } \\
\hline 2 & $0.92 * * *$ & 0.064 & $1.01 * * *$ & 0.056 & $1.18 * * *$ & 0.049 & $1.09 * * *$ & 0.005 & $0.55 * * *$ & 0.021 \\
\hline 3 & $1.05 * * *$ & 0.086 & $1.09 * * *$ & 0.077 & $1.29 * * *$ & 0.070 & $0.97 * * *$ & 0.007 & $0.46^{* * * *}$ & 0.027 \\
\hline 4 & $1.18^{* * * *}$ & 0.121 & $1.02 * * *$ & 0.109 & $1.43^{* * * *}$ & 0.106 & $0.89 * * *$ & 0.011 & 0.46 *** & 0.038 \\
\hline 7 & $1.29 * *$ & 0.421 & 0.56 & 0.389 & $1.39 * *$ & 0.477 & $0.91^{* * *}$ & 0.048 & $0.44^{* * *}$ & 0.133 \\
\hline All & $0.97 * * *$ & 0.034 & $0.90 * * *$ & 0.029 & $1.07 * * *$ & 0.026 & $0.97 * * *$ & 0.003 & $0.49 * * *$ & 0.011 \\
\hline
\end{tabular}

$* * P<0.01 ; * * * P<0.001$

for all 8 parities of Holsteins and Jerseys. Almost all (16 of 18) of the remaining regression coefficients within parity for Ayrshires, Brown Swiss, and Guernseys were positive. All regressions of calving age on year of first calving were significant $(P<0.01)$ except for fourth through eighth parities of Brown Swiss and for third parity of Guernseys. The majority of regressions (29 of 40) for individual parities and all regressions across parity were significant at $P<0.001$. Quadratic regressions (not shown) were compared with linear regressions. Quadratic regressions generally produced higher $\mathrm{R}^{2}$ than did linear regressions for predicting change in calving age over time within and across parity, particularly for Holsteins and Jerseys. Inclusion of both linear and quadratic coefficients was beneficial for all breeds except Guernsey.

Nieuwhof et al. (1989b) indicated that differences in means for calving ages underestimated corresponding differences in means for calving intervals. They attributed this finding to culling, which resulted in inclusion of data from different cows in the parity means for the 2 traits. Therefore, means for calving intervals should not be derived from differences in means for calving ages (such as those presented in Table 2). Cows continued to initiate lactations at younger ages during the 1980 s and 1990s. Calving age by year of first calving is depicted in Figure 1 for parity 1 and in Figure 2 for parity 2 . For 2004, age at first calving ranged from 24.1 mo for Jerseys to 28.3 mo for Ayrshires. Age at second calving declined less than age at first calving for all breeds. Figure 3 shows distribution of Holstein ages at first calving in 1980 and 2004. Although mean calving age decreased for first parity, calving ages were more uniform and centered near 24 mo. An examination of the corresponding Jersey distribution (not shown) indicated a smaller change in variation between 1980 and 2004 compared with the change for Holsteins.

Mean calving intervals are presented in Table 4 by breed and parity. Over all parities, Jerseys had the shortest calving interval (390 d) with intermediate intervals for Ayrshires (398 d) and Holsteins (404 d) and longest intervals for Guernseys (406 d) and Brown Swiss ( $407 \mathrm{~d}$ ). Calving intervals across all parities were longer than those reported by Nieuwhof et al. (1989b) by 2 to $10 \mathrm{~d}$ for all breeds; the smallest increases ( 2 to $3 \mathrm{~d}$ ) were noted for Jerseys, and the largest increases (6 to $10 \mathrm{~d}$ ) were noted for Guernseys and Holsteins. The trend for longer calving intervals confirms that observed in USDA studies (USDA, 2002b) between 1991 and 2002 that calving interval has been increasing in all herds and is in agreement with those in most major dairy countries that select for higher milk and component yields (Lucy, 2001; Murray, 2003; Wall et al., 2003; González-Recio et al., 2004; Nederlands Rundvee Syndicaat, 2005).

Calving intervals continued to increase throughout the 1980s and 1990s. Calving interval by year of first calving is presented in Figure 4 for the interval between first and second parities and in Figure 5 for the interval between second and third parities. The interval be-

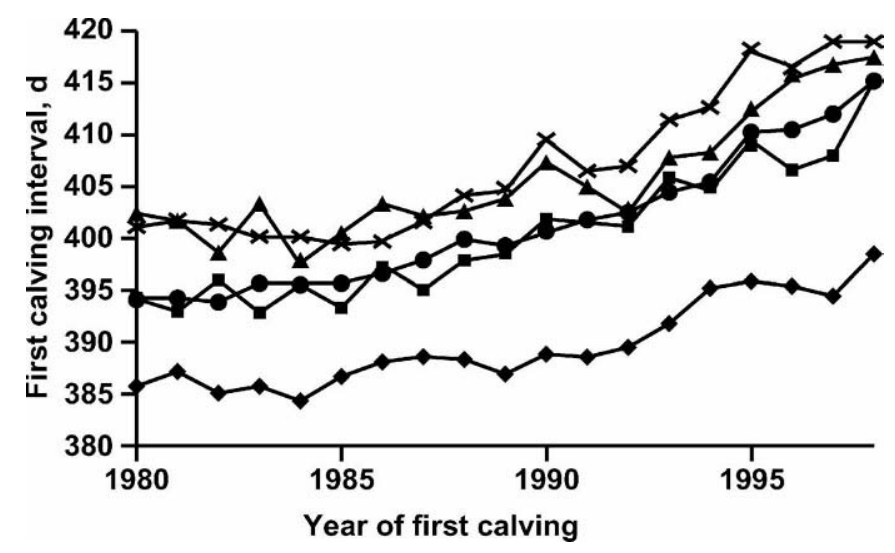

Figure 4. Trend in calving interval between first and second parities by year of first calving for Ayrshires ( $)$, Brown Swiss ( $)$, Guernseys $(\times)$, Holsteins $(\bullet)$, and Jerseys $(\bullet)$. 
tween first and second parities ranged from 399 to 419 $\mathrm{d}$ across breeds for 1998 . The interval between second and third parities was shorter than the first calving interval for Ayrshires and Jerseys, but the second calving interval was similar to the first for other breeds. The longer calving intervals in recent years offset much of the effect of younger calving ages observed for first parity (Figure 1).

Linear regressions of calving interval on year of first calving (Table 5) were positive and significant $(P<$ 0.001 ) across most parities for all breeds. Within parity, regressions of calving interval on year of first calving were positive and significant $(P<0.001)$ for the first 6 calving intervals for all breeds and for the seventh calving interval for 2 breeds. When quadratic regressions (not shown) were compared with linear regressions, linear regressions produced higher $\mathrm{R}^{2}$ for 30 of 40 breedparity tests. Only for a few tests did inclusion of both linear and quadratic coefficients provide an appreciable increase in $R^{2}$ above that from either linear or quadratic regression, even though the coefficients were sometimes significant $(P<0.05)$ because of the large number of observations. When parity was not considered, annual increases in calving interval were fairly consistent $(0.90$ to $1.07 \mathrm{~d} / \mathrm{yr})$ for all breeds except Jersey (0.49 $\mathrm{d} / \mathrm{yr})$. Similar increases were found within parity $(0.39$ to $0.62 \mathrm{~d} / \mathrm{yr}$ for Jerseys and 0.88 to $1.60 \mathrm{~d} / \mathrm{yr}$ for other breeds) except for seventh calving interval of Brown Swiss $(0.56 \mathrm{~d} / \mathrm{yr})$.

\section{CONCLUSIONS}

Younger ages at first calving and longer calving intervals have continued with time for all breeds. The decline in calving age across years observed for early parities has not always carried throughout later parities because of increased calving intervals. First calving age ranged from 24 mo for Jerseys to 28 mo for Ayrshires in 2004. Mean calving age ranged from 48 mo for Holsteins to 54 mo for Ayrshires in 2004. Means across years indicate that the age of the dairy population is declining, most likely because of higher culling rates. Mean calving interval across parity was shortest for Jerseys (390 d) and longest for Brown Swiss (407 d). The trend for longer calving interval has continued and was similar (0.90 to $1.07 \mathrm{~d} / \mathrm{yr}$ ) for all breeds except Jersey $(0.49 \mathrm{~d} / \mathrm{yr})$. Perhaps the availability of genetic evaluations for daughter fertility will alter this trend.

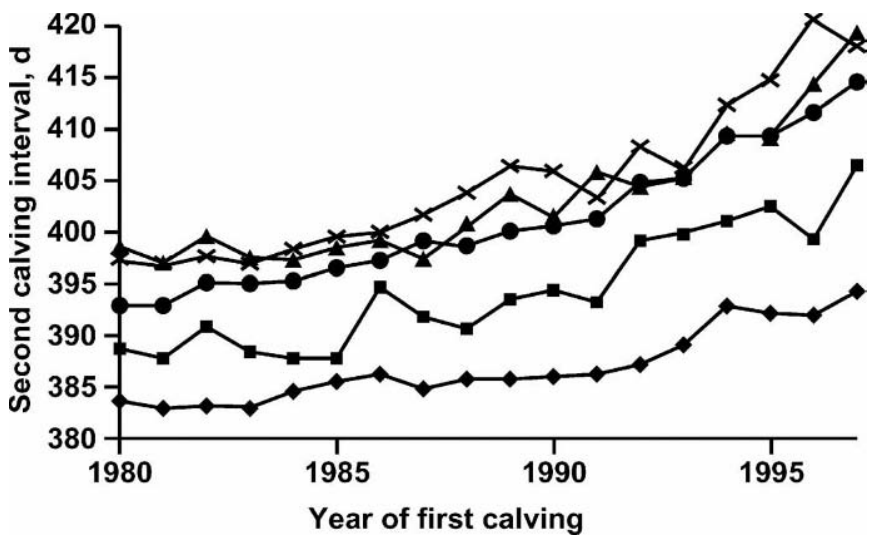

Figure 5. Trend in calving interval between second and third parities by year of first calving for Ayrshires (অ), Brown Swiss ( $\mathbf{(})$, Guernseys ( $\times$ ), Holsteins (๑), and Jerseys $(\bullet)$.

\section{REFERENCES}

Animal Improvement Programs Laboratory. 2005. Genetic and phenotypic trends. Online. Available: http://aipl.arsusda.gov/dynamic/trend/current/trndx.html Accessed Apr. 20, 2005.

González-Recio, O., M. A. Pérez-Cabal, and R. Alenda. 2004. Economic value of female fertility and its relationship with profit in Spanish dairy cattle. J. Dairy Sci. 87:3053-3061.

Gröhn, Y. T., and P. J. Rajala-Schultz. 2000. Epidemiology of reproductive performance in dairy cows. Anim. Reprod. Sci. 6061:605-614.

Lucy, M. C. 2001. Reproductive loss in high-producing dairy cattle: Where will it end? J. Dairy Sci. 84:1277-1293.

Murray, B. 2003. Balancing act - Research shows we are sacrificing fertility for production traits. Publ. 81-093. Ontario Ministry Agric. Food, Toronto, Canada.

Nederlands Rundvee Syndicaat. 2005. Jaarstatistieken 2004. Coöperatie Rundveeverbetering Delta, Arnhem, The Netherlands.

Nieuwhof, G. J., H. D. Norman, and F. N. Dickinson. 1989a. Phenotypic trends in herdlife of dairy cows in the United States. J. Dairy Sci. 72:726-736.

Nieuwhof, G. J., R. L. Powell, and H. D. Norman. 1989b. Ages at calving and calving interval for dairy cattle in the United States. J. Dairy Sci. 72:685-692.

USDA. 2002a. Dairy 2002. Part I: Reference of dairy health and management in the United States, 2002. Rep. N377.1202. National Animal Health Monitoring System, Animal and Plant Health Inspection Service, USDA, Fort Collins, CO.

USDA. 2002b. Dairy 2002. Part II: Changes in the United States dairy industry, 1991-2002. Rep. N399.0603. National Animal Health Monitoring System, Animal and Plant Health Inspection Service, USDA, Fort Collins, CO.

VanRaden, P. M., and E. J. H. Klaaskate. 1993. Genetic evaluation of length of productive life including predicted longevity of live cows. J. Dairy Sci. 76:2758-2764.

VanRaden, P. M., A. H. Sanders, M. E. Tooker, R. H. Miller, H. D. Norman, M. T. Kuhn, and G. R. Wiggans. 2004. Development of a national genetic evaluation for cow fertility. J. Dairy Sci. 87:2285-2292.

Wall, E., S. Brotherstone, J. A. Woolliams, G. Banos, and M. P. Coffey. 2003. Genetic evaluation of fertility using direct and correlated traits. J. Dairy Sci. 86:4093-4102. 